\title{
Structuring and Restructuring Sovereign Debt: The Role of a Bankruptcy Regime
}

\section{Patrick Bolton}

Columbia University, National Bureau of Economic Research, Center for Economic Policy

Research, and European Corporate Governance Institute

Olivier Jeanne

International Monetary Fund and Center for Economic Policy Research

\begin{abstract}
In an environment characterized by weak contractual enforcement, sovereign lenders can enhance the likelihood of repayment by making their claims more difficult to restructure ex post. We show, however, that competition for repayment between lenders may result in a sovereign debt that is excessively difficult to restructure in equilibrium. This inefficiency may be alleviated by a suitably designed bankruptcy regime that facilitates debt restructuring.
\end{abstract}

\section{Introduction}

The composition of sovereign debt and how it affects debt restructuring negotiations in the event of financial distress has become a central policy issue in recent years. There are two major reasons why the spotlight has been turned on this question. First, the change in the International Monetary Fund's (IMF's) policy orientation toward sovereign debt crises, with a proposed greater weight on "private-sector involvement" (Rey Report, G-10 1996), has brought up the question of how easy it actually is to get "the private sector involved," that is, how easy it is to get private

This paper has benefited from the comments of Anil Kashyap (the editor) and three anonymous referees. The views expressed in this paper are those of the authors and should not be attributed to the International Monetary Fund, its Executive Board, or its management.

[Journal of Political Economy, 2007, vol. 115, no. 6]

(C) 2007 by The University of Chicago. All rights reserved. 0022-3808/2007/11506-0004\$10.00 
debt holders to agree to a debt restructuring. Second, the experience with several recent debt restructuring episodes-some of which were followed by defaults and by private litigation to recover debt paymentshas raised concerns that the uncoordinated efforts of dispersed debt holders to renegotiate sovereign debt obligations were likely to lead to substantial delays and other inefficiencies.

These concerns have led a number of prominent commentators, a majority of Group of 7 countries, and the IMF to advocate ex post policy interventions to facilitate debt restructuring. A culmination point for the calls for reform had been reached when the IMF's Anne Krueger put forward the idea of a sovereign debt restructuring mechanism inspired by the U.S. corporate bankruptcy reorganization law under Chapter 11 of the 1978 Bankruptcy Act (Krueger 2002). ${ }^{1}$ However, the ensuing policy debate has left many commentators wondering why, in the first place, sovereign debt had been structured to make it difficult to renegotiate and why the structure of sovereign debt had evolved over the past decade or so toward a greater share of sovereign bond issues and greater dispersion of ownership of sovereign bonds. This article is concerned with precisely these issues. Its starting point is the following questions:

1. Why would a forward-looking sovereign want to design a sovereign debt structure that is difficult to restructure?

2. Where are the contractual failures between the borrower and lenders that justify an ex post policy intervention to facilitate debt restructuring?

Several commentators (Dooley 2000; Shleifer 2003) have argued that because of the sovereign's incentive to repudiate its debts (the wellknown willingness-to-pay problem), it may be ex ante efficient to structure sovereign debt to make it difficult to renegotiate ex post. A policy intervention that aims to reduce these restructuring costs, while improving ex post efficiency, might thus undermine ex ante efficiency. Such a policy would have the effect of raising the cost of borrowing and would result in a reduction of lending to emerging market countries. ${ }^{2}$

Our article builds on this very idea that debts that are more difficult to restructure are less vulnerable to repudiation, but it stops short of concluding that sovereign debt that is difficult to restructure is necessarily ex ante efficient. We add to the theme that lenders seek protection against a generalized default by a sovereign, the idea that individual

\footnotetext{
${ }^{1}$ See Rogoff and Zettelmeyer (2002) for a history and overview of the different proposals. ${ }^{2}$ The idea that under limited enforcement it may be desirable to create a debt structure that is difficult to renegotiate is, of course, a familiar theme in corporate finance. See, e.g., Dewatripont and Maskin (1995), Hart and Moore (1995), Bolton and Scharfstein (1996), Diamond and Rajan (2001), and Diamond (2004).
} 
lenders also seek to protect themselves individually against selective defaults by the sovereign on a subset of its debts. Thus, by attempting to divert a selective default onto other debts, individual lenders may end up providing too much debt that is difficult to restructure. Just as a burglar alarm may be an individually optimal protection against breakins for an individual house owner (by inducing prospective burglars to target other houses without such an alarm system), collectively, having all houses equipped with an alarm could well be self-defeating and inefficient.

By lending in the form of debt that is hard to restructure, individual lenders are able to effectively make their debts more senior to other debts that are easier to restructure and, therefore, more likely to be selected for a default by the sovereign ex post. Or, put differently, with each debt issue, the sovereign may attempt to lower the cost of borrowing by committing to high future restructuring costs of that particular issue and thus providing a form of seniority to that issue. This de facto seniority can be obtained in various ways, for example, by lifting sovereign immunity, by widely dispersing the debt and insisting on a unanimity requirement for restructuring the debt, by lowering the maturity of the debt, by denominating the debt in dollars, or by inserting acceleration clauses. Thus, a form of Gresham law for sovereign debt may arise; bad debt structures that are hard to restructure tend to crowd out good debts that are easier to renegotiate.

Our article argues that there is, therefore, a role for policy intervention in sovereign lending that would improve both ex ante and ex post efficiency. This policy intervention should take the general form of facilitating the restructuring of hard debt. Thus, our theory has some implications for the reforms of the international financial architecture that have been discussed in recent debates, and in particular the desirability of a bankruptcy regime for sovereigns. We argue that because of the competition between lenders to deflect a selective default, sovereign debt might be excessively hard to restructure in equilibrium even from an ex ante perspective. A bankruptcy regime for sovereigns could then mitigate this inefficiency by facilitating debt restructuring in a sovereign debt crisis.

In our model, the contractual approach to sovereign debt restructuring endorsed by the official community, ${ }^{3}$ which is limited to moral suasion over issuers to introduce majority-rule clauses for the restructuring of debt in bond issues (so-called collective action clauses or

\footnotetext{
${ }^{3}$ The contractual approach advocated by the official sector is outlined in G-10 (1996) and G-22 (1998).
} 
CACs), does not work. ${ }^{4}$ As we show, efficiency cannot be achieved by leaving sovereign borrowers free to include or not renegotiation-friendly clauses in their debt. In equilibrium, the adoption of such clauses will be inefficiently low. However, a policy that encourages the adoption of such clauses through a system of taxes or subsidies or other arm-twisting (as advocated by Kenen [2001] or Eichengreen [2003]), or by making their use mandatory, could achieve the same effect as a restructuring under a bankruptcy regime.

Although our analysis provides support for a bankruptcy regime or some form of mandated or subsidized CACs, we also emphasize that such an intervention may easily be welfare reducing if it is not carefully designed. Indeed, it could undermine sovereign debt markets if it gives too little bargaining power to lenders in a renegotiation.

Our article contributes to the literature on sovereign debt default and restructuring. A number of authors have emphasized the importance of selective default in sovereign debt. Dooley (2000) and Kenen (2001), for example, emphasize the conflict between official and private lenders in the competition for repayment. Tirole (2002, chap. 4) discusses the contracting externalities arising from selective default and mentions seniority as a possible solution to this problem. In our companion paper (Bolton and Jeanne 2005), we analyze a dynamic model of sovereign debt and focus on the problem of debt dilution induced by selective defaults. We show how the resulting inefficiency can be mitigated by the enforcement of a de jure seniority rule for sovereign debt. As we document in Section II, practitioners also pay a great deal of attention to the implicit seniority status of the different types of sovereign debt. However, although commentators and practitioners are aware of the issue, the implications of selective default on sovereign debt to our knowledge have not been explored systematically before.

This article is structured as follows. Section II reviews some stylized facts on sovereign debt that motivate the theoretical analysis in the rest of the paper. Section III lays out the model and basic assumptions. Section IV characterizes the socially efficient debt structure. Section V analyzes equilibrium debt structures. Section VI discusses public policy implications, and Section VII presents conclusions.

\section{Evidence on Selective Defaults}

This section presents evidence suggesting that there is an implicit seniority structure for sovereign debt and that this structure is related to

\footnotetext{
${ }^{4}$ Collective action clauses facilitate bond restructurings by lowering the threshold for agreement of a restructuring by bondholders from unanimity to a 75 percent supermajority rule.
} 
the perceived difficulty with which debt can be restructured. The implicit seniority in sovereign debt is an understudied topic, on which there has been little empirical and theoretical research. We will present a few facts as well as market commentaries that suggest that seniority is a real issue for sovereign debt structuring and restructuring. The interested reader will find more detailed discussions of the evidence in Zettelmeyer (2003), Roubini and Setser (2004), and Sturzenegger and Zettelmeyer (2006).

The de facto seniority structure of sovereign debt is, for one thing, apparent from the different treatment of different classes of creditors in a default. The differential treatment of claims has been a characteristic of most debt restructurings that have taken place over the last 25 years (beginning with the debt renegotiations and write-downs of the 1980s and the Brady plan and continuing with the more recent debt restructurings in Russia, Ukraine, Pakistan, Ecuador, and Uruguay). This differential treatment has taken the form not only of entirely excluding some debts (in particular, multilateral official debt) from debt restructurings, but also of negotiating more favorable deals for subclasses of private claims. Thus, for example, the "Brady deals" that settled the debt crises of the 1980s restructured bank loans but not international bonds (Merrill Lynch 1995).

More recently, the composition of sovereign debt has shifted away from syndicated bank loans, which were the dominant form of lending in the 1970s and 1980s, toward bond finance (fig. 1). While there is no single cause that explains this change in composition, one reason, undoubtedly, has been the perception, following the debt crises of the 1980s and the Brady deals, that syndicated bank loans were too easy to restructure. In valuing the new bond issues, at least some lenders have factored in a lower risk of restructuring of international bonds. To the extent that these bond issues were widely dispersed, they were perceived to be more difficult to restructure and therefore less likely to be restructured in a debt crisis: "There are several things that make international bonds much harder to restructure than loans. First, they typically involve many more investors than do loans, even syndicated loans. Second, they may be in bearer form so investors may be untraceable" (Peterson 1999).

The debt crises and defaults of Russia (1998-2000) and Argentina (2001-5) have highlighted just how difficult comprehensive debt restructuring negotiations can be, when they involve hundreds of thousands of different bondholders with a wide variety of objectives. ${ }^{5}$

\footnotetext{
${ }^{5}$ Debt restructuring has been facilitated, in some cases, by the creative use of exit consent clauses (Buchheit and Gulati 2000), leading Roubini and Setser (2004) to conclude that the lack of creditor coordination has been overstated as an impediment to debt restructuring. However, the expectation that bonded debt would be difficult to restructure seems
} 


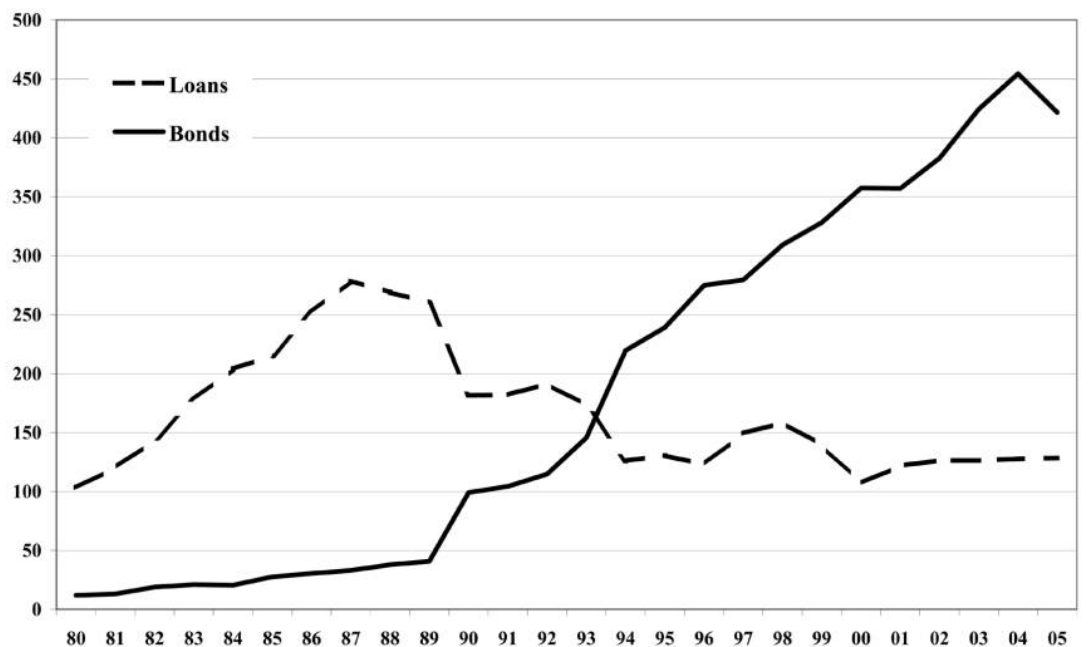

Fig. 1.-Structure of external public debt of middle-income countries: bonds vs. loans (1980-2005, in billions of U.S. dollars). Source: World Bank's Global Development Finance database. The figure shows the outstanding aggregate stock of privately held long-term public and publicly guaranteed debt for middle-income countries in the form of bonds and commercial bank loans.

Following more than three years of listless negotiations, the Argentine government launched a global debt exchange for 152 different securities amounting to 60 percent of its GDP. Although the exchange has been accepted by a majority of creditors, the legal status of this debt restructuring remains in doubt since many bond issues required unanimous consent from the bondholders to be restructured. The Argentine government has since had to face a large number of creditor lawsuits that are still pending at the time of writing, and Argentina has still not regained access to the international capital market. ${ }^{6}$

During most of the 1990s the differential treatment of sovereign claims has followed a pattern that is consistent with an implicit seniority of international bonds over international bank loans. A total of 93 sovereigns have defaulted on their syndicated bank loans since 1975, including 20 that had bonds outstanding at the same time that their bank loans were in default. Yet only nine out of these 20 sovereigns also

to have played a significant role in shaping the equilibrium structure of sovereign debt in the $1990 \mathrm{~s}$.

${ }^{6}$ It has been argued that the flow cost of market exclusion did not seem to be very high, by the evidence of the Argentine growth rate in recent years. Still, the economic disruption associated with the default, especially in the domestic banking sector, exacted a steep cost in terms of output collapse in the first year following the default (GDP fell by more than 15 percent in 2001-2). 
defaulted on their bonds, and the others serviced them in full (Beers and Chambers 2003).

The restructuring of Russian sovereign debt (1998-2000) is typical of this pattern. Domestic debt and Soviet-era London and Paris Club debts have been restructured, whereas Eurobonds have been left untouched. Market participants have viewed this latest Russian debt restructuring episode as further corroboration of the sovereigns' tendency of treating creditors differently according to their power of nuisance.

Market participants were also well aware that such behavior resulted in an implicit seniority structure affecting the pricing and valuation of debt:

It is that implicit seniority which, in part, explains why bonds have become such favoured instruments for countries raising debt in recent years, says Ernesto Martinez Alas, an analyst at Moody's. (Peterson 1999, 50)

The majority of governments treated bonds as being effectively senior to bank loans, and they did so with the tacit consent of bank creditors. (Beers and Chambers 2003)

In summary, the evidence points to the following stylized facts that our theory will attempt to capture and explain:

- Sovereigns do not default in the same way on different classes of debt instruments, and this selectivity generates an implicit seniority between debt classes.

- Seniority seems related to structural features of sovereign debt that make it more or less easy to renegotiate with creditors.

- International investors are aware of this implicit seniority structure and pay close attention to potential shifts in its determinants.

- The composition of international sovereign debt has shifted to the class of instruments that was perceived as senior during the 1990s.

\section{The Model: Assumptions}

We consider a small open economy over two periods with a single homogeneous good that can be consumed or invested. The representative resident of this economy may raise funds from the rest of the world by issuing (sovereign) debt in the first period $(t=1)$ to be repaid in the next period $(t=2)$. The funds raised in the first period can be used for consumption or investment purposes.

To keep the analysis as tractable as possible, we specify the following 
simple form for the utility function of the representative resident:

$$
\begin{aligned}
& U_{2}=V(g)+c, \\
& U_{1}=E_{1}\left(U_{2}\right),
\end{aligned}
$$

where $g$ is the level of public expenditure in period 1 and $c$ is private consumption in period 2. The sovereign is assumed to act on behalf of the representative resident and maximizes her welfare.

The representative resident receives an exogenous stochastic endowment $y$ in period 2, which is distributed according to the probability distribution function $f(\cdot)$. Again for simplicity we shall assume that there is no taxable output in period 1 so that the government finances $g$ entirely by borrowing from foreign lenders. We shall assume that $g$ is exogenously given and is such that $0<g<E(y)$, where $E(y)$ denotes the expected endowment in period $2 .^{7}$

In reality most sovereigns' borrowing needs are such that they have no choice but to borrow from multiple lenders. When a sovereign borrows from different lenders, the issue of strategic default is more complex since the sovereign can choose to selectively default on some of the lenders and not on others. Accordingly, any individual lender will be concerned not only about the risk of a full default by the sovereign but also about the relative risk of a selective default on its own debt. An individual lender can guard himself to some extent against the risk of a selective default by lending through a debt instrument that is difficult to restructure. Thus, to allow for multiple lenders, as well as different types of debts in terms of how difficult they are to restructure, we shall model the sovereign debt lending game as follows.

\section{A. Lending Game}

In period 1 there is a continuum of atomistic lenders (indexed by $i \in I$ ) from which the sovereign can borrow. Each of these lenders is able to lend $g$, so that the sovereign must borrow from a subset of mass one of lenders. The total mass of lenders is large, ensuring that perfect competition prevails and lenders do not extract any rent. The lenders have access to a zero-return storage technology.

The lending game can be viewed as a general (common agency) contracting game between a principal (the sovereign) and multiple agents (the lenders) as, for example, in Bernheim and Whinston (1986a, 1986b), Hart and Tirole (1990), or Segal (1999). Specifically, we follow Segal by letting lenders participate in a bidding game following the

\footnotetext{
${ }^{7}$ See Bolton and Jeanne (2005) for a more general model in which $g$ is optimally determined by the sovereign.
} 
sovereign's announcement of a fund-raising goal of $g$. Lenders move first by each simultaneously making a bid. The sovereign then decides which bids to accept.

At the bidding stage of the game each lender $i$ makes an offer $d(i)$ of the period 2 debt repayment in exchange for a loan $g$. We assume that there are two types of lenders: those with whom the sovereign can renegotiate the repayment of the debt (denoted by $r$ ) and those with whom renegotiation is impossible (denoted by $n$ ). We explain below the precise difference in our model between renegotiable and nonrenegotiable debt.

In the second stage of the bidding game the sovereign chooses which bids to accept. The sovereign selects the bids that maximize domestic welfare and selects randomly between identical bids. At the end of the bidding game the sovereign is thus potentially indebted to two classes of creditors: r-creditors (the holders of renegotiable debt) and n-creditors (the holders of nonrenegotiable debt).

The lenders' utility is equal to their period 2 consumption. Finally, a Nash equilibrium of the lending game is defined as a set of bids $(d(i))_{i \in I}$ such that, for all $i$, bid $d(i)$ maximizes lender $i$ 's utility taking all the other bids $d(j), j \neq i$, as given.

The noncooperative nature of the game reflects the idea that it is difficult for lenders to coordinate themselves or be coordinated by the sovereign. Given that there is an excess supply of lenders, the lenders attempt to win the lending contest by offering the most attractive terms to the government. Therefore, one should expect an equilibrium outcome in which the sovereign receives all the surplus from the lending relationship.

\section{B. Repayment Game}

We shall denote by $N_{r}$ and $N_{n}$ the respective mass of r-creditors and ncreditors $\left(N_{r}+N_{n}=1\right)$. We look at symmetric equilibria in which all creditors of a given type $\theta=r, n$ make the same bid $d_{\theta}$, so that the sovereign's total repayments of renegotiable debt and nonrenegotiable debt that come due in period 2 are

$$
d_{r} N_{r}+d_{n} N_{n} \equiv D_{r}+D_{n}
$$

The promise to repay $D_{r}+D_{n}$ is credible only if it is in the sovereign's interest to repay its debt obligations ex post. We follow the sovereign debt literature by assuming that the sovereign repays its debts only as a way of avoiding a costly default. As in Sachs and Cohen (1982) and Obstfeld and Rogoff (1996), we model the cost of default as a propor- 
tional output loss, $\gamma y .{ }^{8}$ We interpret this cost as a sanction imposed by creditors on the defaulting sovereign (see Bulow and Rogoff [1989] for a discussion of such sanctions). ${ }^{9}$ To simplify the algebra, and without loss of generality, we assume that $\gamma=1$, so that creditors can destroy all the resources of a defaulting sovereign.

For simplicity we assume that renegotiable debt can be renegotiated at no cost, but that nonrenegotiable debt is impossible to renegotiate since these debts are too widely dispersed and since a unanimous agreement is required to renegotiate the debt. ${ }^{10}$ For example, one can think of the renegotiable debt as syndicated bank loans and nonrenegotiable debt as bonds held by a large number of dispersed bondholders.

The sovereign is always better off repaying the n-creditors than losing all the domestic output because of the sanctions. Thus a full default (on both types of creditors) will occur only if the sovereign is unable to repay the n-creditors:

$$
y<D_{n} .
$$

The sovereign could also renegotiate the repayment of its r-debt while it repays fully its n-debt (selective default). We shall assume that in a selective default, $r$-creditors receive a fraction $\omega \in[0,1]$ of the net surplus from renegotiation $y-D_{n}$ (net after repayment of the n-creditors). It follows that the sovereign chooses a selective default over full repayment if

$$
y-D_{n}-\omega\left(y-D_{n}\right)>y-D_{n}-D_{r}
$$

or if

$$
y<D_{n}+\frac{D_{r}}{\omega} .
$$

In summary, the payoffs of the different players in the selective default

\footnotetext{
${ }^{8}$ It is generally assumed in the literature that the cost of defaulting is the same whether the sovereign defaults in full or whether it repays part of its debt. This is a somewhat extreme assumption. One might want to consider the more general default cost function $\gamma(s) y$, where $\gamma(s)$ is increasing in the repayment shortfall $s$ from zero to a maximum value, $\bar{\gamma}<1$. Our analysis would be virtually unchanged if we allowed for this more general default cost function.

${ }^{9}$ Another approach views the cost of default as a loss of reputation (e.g., Eaton and Gersovitz 1981). See Bolton and Jeanne (2005) for a model of sovereign debt restructuring that includes both types of cost.

${ }^{10}$ The inability to renegotiate the debt ex post may be to the detriment of bondholders' collective interests. Even so, because of a free-rider problem-as in Diamond and Rajan (2001) or Jeanne (2004) — widely dispersed debts will not be renegotiable ex post. For example, individual litigating creditors could hope to seize some collateral but might impose an output cost on the country that is much larger than the value of collateral that they can seize collectively. Similarly, the bondholders may be unable to accept a voluntary decentralized debt exchange or repurchase, even an efficient one, because of free riding by holdouts (Bulow and Rogoff 1991).
} 
TABLE 1

The Sovereign's and Creditors' Payoffs in the Repayment Game

\begin{tabular}{lccc}
\hline \hline & Full Default & Selective Default & Full Repayment \\
\hline & $y<D_{n}$ & $D_{n} \leq y<D_{n}+\left(D_{r} / \omega\right)$ & $D_{n}+\left(D_{r} / \omega\right) \leq y$ \\
Sovereign & 0 & $(1-\omega)\left(y-D_{n}\right)$ & $y-D_{r}-D_{n}$ \\
r-creditors & 0 & $\omega\left(y-D_{n}\right)$ & $D_{r}$ \\
n-creditors & 0 & $D_{n}$ & $D_{n}$ \\
\hline
\end{tabular}

game are given in table 1 . And we obtain the following result characterizing ex post equilibrium default.

Proposition 1. The sovereign's debt repayment strategy is as follows:

a. Full repayment: If $y \geq D_{n}+\left(D_{r} / \omega\right)$, the sovereign fully repays both types of debt.

b. Selective default: If $D_{n} \leq y<D_{n}+\left(D_{r} / \omega\right)$, the sovereign fully repays the nonrenegotiable debt and agrees on a reduction of the renegotiable debt to $\omega\left(y-D_{n}\right)$ with the r-creditors.

c. Full default: If $y<D_{n}$, the sovereign defaults on both types of debt.

Proof. See the discussion above.

This proposition highlights the notion that nonrenegotiable debt is effectively senior to renegotiable debt. In the event of a selective default, the allocation of the repayments between r-creditors and n-creditors is the same as if the latter enjoyed strict seniority over the former.

\section{Optimal Debt Structure}

As a benchmark, we begin by characterizing the debt structure chosen by a social planner, subject to the lenders' participation constraints. That constraint is given by

$$
V\left(D_{r}, D_{n}\right) \geq g
$$

where $V\left(D_{r}, D_{n}\right)$, the lenders' total expected payoff, is given by

$$
\begin{aligned}
V\left(D_{r}, D_{n}\right)= & \int_{D_{n}}^{D_{n}+\left(D_{r} / \omega\right)}\left[\omega y+(1-\omega) D_{n}\right] f(y) d y \\
& +\left(D_{r}+D_{n}\right) \int_{D_{n}+\left(D_{r} / \omega\right)}^{+\infty} f(y) d y .
\end{aligned}
$$

The sovereign's ex ante welfare can be written as the utility of the public expenditure $g$ plus the total final expected surplus net of the agency costs of debt, or 


$$
\begin{aligned}
U\left(D_{r}, D_{n}\right)= & V(g)+\int_{D_{n}}^{D_{n}+\left(D_{r} / \omega\right)}(1-\omega)\left(y-D_{n}\right) f(y) d y \\
& +\int_{D_{n}+\left(D_{r} / \omega\right)}^{+\infty}\left(y-D_{r}-D_{n}\right) f(y) d y, \\
= & V(g)+E(y)-V\left(D_{r}, D_{n}\right)-L\left(D_{n}\right),
\end{aligned}
$$

where the expected deadweight loss $L\left(D_{n}\right)$ is given by the expected value of the output lost in a full default:

$$
L\left(D_{n}\right)=\int_{0}^{D_{n}} y f(y) d y
$$

The optimal debt structure thus minimizes the deadweight loss (or, equivalently, the probability of a full default) subject to meeting the lenders' participation constraint:

$$
\begin{aligned}
& \min _{D_{n} D_{n}} L\left(D_{n}\right) \\
& \text { subject to } V\left(D_{r}, D_{n}\right) \geq g .
\end{aligned}
$$

The deadweight loss is reduced to zero, therefore, if and only if there is no nonrenegotiable debt, ${ }^{11}$

$$
D_{n}=0 .
$$

However, it may not be possible for the social planner to finance $g$ when $D_{n}=0$. For a given level of nonrenegotiable debt $D_{n}$, the level of expected output that the sovereign can credibly pledge to foreign lenders is maximized when $D_{r}$ goes to infinity, and the maximum pledgeable output is given by ${ }^{12}$

$$
\bar{V}\left(D_{n}\right)=\int_{D_{n}}^{+\infty}\left[\omega y+(1-\omega) D_{n}\right] f(y) d y .
$$

The sovereign can finance $g$ without taking the risk of a full default if $\bar{V}(0)=\omega E(y) \geq g$, that is, if the bargaining power of the r-creditors is sufficiently large:

${ }^{11}$ This result is due to our assumption that output realizations can be arbitrarily small. If the distribution of output had a strictly positive lower bound $\underline{y}$, then a zero deadweight loss would require only that $D_{n} \leq y$. Our results can be generalized to this case without difficulty.

${ }^{12}$ Differentiating (2) shows that $V$ is increasing with $D_{r}$. 


$$
\omega \geq \omega^{*} \equiv \frac{g}{E(y)}
$$

If this condition is not satisfied, the sovereign chooses the lowest level of $D_{n}$ that is consistent with the lenders' participation constraint $\bar{V}\left(D_{n}\right)=g$. The optimal level of $D_{n}$ is decreasing with $\omega$ because $\bar{V}(\cdot)$ increases with $\omega$. An increase in the creditors' bargaining power allows the sovereign to pledge them more output and thus to decrease its reliance on nonrenegotiable debt. Conversely, in the limit case in which creditors have no bargaining power $(\omega=0)$, the sovereign must finance $g$ entirely with nonrenegotiable debt. We assume that this is possible because $\max _{D_{n}} V\left(0, D_{n}\right) \geq g$.

Our results on the first-best debt structure are summarized in the proposition below.

Proposition 2. Assume that the sovereign debt structure is chosen by a social planner. Then there is a threshold in the creditors' bargaining power, $\omega^{*}=g / E(y)$, such that (1) if $\omega<\omega^{*}$, a fraction of the sovereign debt is nonrenegotiable; this fraction is decreasing with $\omega$; (2) if $\omega \geq$ $\omega^{*}$, the sovereign's debt is entirely renegotiable.

Proof. See the discussion above.

Nonrenegotiable debt may have a role to play because it is a "hard claim" that allows the sovereign to pledge more domestic output to foreign creditors. If renegotiable debt is too "soft" (because creditors have too little bargaining power), some nonrenegotiable debt might be required to harden the overall debt structure.

\section{Equilibrium Debt Structure}

As we shall show in this section, when the sovereign borrows from multiple uncoordinated lenders, the equilibrium sovereign debt structure includes an excessive level of nonrenegotiable debt. The reason is simply that for some lenders a best response to other lenders' bids is to submit a bid in the form of nonrenegotiable debt as a way of deflecting a possible selective default onto other debt issues. Moreover, the sovereign will accept these bids because they involve a lower cost of capital.

We denote by, respectively, $V_{r}$ and $V_{n}$ the total expected payoff of holding r-debt, $D_{r}$, and n-debt, $D_{n}$. Similarly, we denote by $P_{r}$ and $P_{n}$ the fair prices of renegotiable and nonrenegotiable debts:

$$
P_{r}=\frac{V_{r}}{D_{r}}=\int_{D_{n}}^{D_{n}+\left(D_{r} / \omega\right)} \frac{\omega\left(y-D_{n}\right)}{D_{r}} f(y) d y+\int_{D_{n}+\left(D_{r} / \omega\right)}^{+\infty} f(y) d y
$$


and

$$
P_{n}=\frac{V_{n}}{D_{n}}=\int_{D_{n}}^{+\infty} f(y) d y .
$$

Thus, $P_{r}$ and $P_{n}$ are the dollar values of one dollar of repayment of renegotiable and nonrenegotiable debt. One can check that nonrenegotiable debt is worth more on the dollar than renegotiable debt by computing

$$
P_{n}-P_{r}=\frac{\omega}{D_{r}} \int_{D_{n}}^{D_{n}+\left(D_{r} / \omega\right)}\left(D_{n}+\frac{D_{r}}{\omega}-y\right) f(y) d y>0 .
$$

The price difference reflects the effective seniority of nonrenegotiable debt over renegotiable debt in the event of a selective default.

In a Nash equilibrium of the lending game the pair of debt repayments $\left(d_{r}, d_{n}\right)$ must be such that no lender has a strict incentive to deviate by offering a different type of debt or a different face value. Moreover, if the sovereign borrows from lenders of type $\theta=r, n$, those lenders must just break even: $P_{\theta} d_{\theta}=g$. Indeed, those lenders would be better off not lending if the repayment $d_{\theta}$ were such that $P_{\theta} d_{\theta}<g$. Similarly, as there is an excess mass of lenders, there would be a profitable deviation for any individual lender if the repayments $d_{\theta}$ were such that $P_{\theta} d_{\theta}>g$ of bidding $d_{\theta}-\varepsilon$ (where $\varepsilon>0$ is arbitrarily small) and thus securing a profitable loan with probability one.

Consider next the sovereign's problem. After lenders have made their bids $\left(d_{r}, d_{n}\right)$, the sovereign chooses the debt structure that maximizes domestic welfare subject to meeting the sovereign's financing constraint:

$$
\begin{aligned}
& \max _{D_{r} D_{n}} U\left(D_{r}, D_{n}\right) \\
& \text { subject to } \frac{D_{r}}{d_{r}}+\frac{D_{n}}{d_{n}}=1, D_{r} \geq 0, D_{n} \geq 0,
\end{aligned}
$$

where $D_{\theta} / d_{\theta}=N_{\theta}$ is the number of creditors of type $\theta$.

We distinguish between two types of equilibria: (1) interior equilibria, in which the sovereign issues both types of debt $\left(D_{r}>0\right.$ and $\left.D_{n}>0\right)$; and (2) corner equilibria, in which the sovereign issues one type of debt only $\left(D_{r}=0\right.$ or $\left.D_{n}=0\right)$.

The equilibrium debt structure can then be characterized in two steps. First, we show that an interior equilibrium cannot exist.

Lemma 1. A Nash equilibrium of the lending game is such that the sovereign borrows in the form of either fully renegotiable $\left(D_{n}=0\right)$ or fully nonrenegotiable $\left(D_{r}=0\right)$ debt.

Proof. See the Appendix.

Only two corner equilibria can exist because the sovereign's objective 
function is convex in $D_{r}$ and $D_{n}$. Therefore, the sovereign, who can borrow arbitrary quantities of debt at given prices, always chooses a corner solution and issues only one type of debt.

A corner equilibrium with debt of type $\theta$ in turn exists if and only if a lender of type $\theta^{\prime} \neq \theta$ cannot deviate by making a profitable offer that is accepted by the sovereign. A profitable bid must yield a strictly positive net return and be such that

$$
d_{\theta^{\prime}}=\frac{g(1+\alpha)}{P_{\theta^{\prime}}},
$$

where $\alpha>0$ denotes the net return on the bid (if it is accepted). Such a bid would allow the sovereign to make a marginal swap in its debt structure $d D_{\theta}<0$ and $d D_{\theta^{\prime}}>0$ such that

$$
\frac{d D_{\theta}}{d D_{\theta^{\prime}}}=-\frac{d_{\theta}}{d_{\theta^{\prime}}}
$$

In a corner equilibrium, such a deviation should not increase the sovereign's welfare. Or, from

$$
d U=\frac{\partial U}{\partial D_{\theta}} d D_{\theta}+\frac{\partial U}{\partial D_{\theta^{\prime}}} d D_{\theta^{\prime}}
$$

(8), (9), and $g=P_{\theta} d_{\theta}$, this amounts to

$$
d U=\left(-\frac{1}{1+\alpha} \frac{P_{\theta^{\prime}}}{P_{\theta}} \frac{\partial U}{\partial D_{\theta}}+\frac{\partial U}{\partial D_{\theta^{\prime}}}\right) d D_{\theta^{\prime}} \leq 0 .
$$

This condition is necessary and sufficient for the existence of a corner equilibrium with debt of type $\theta$. We then establish the following result.

Lemma 2. A corner equilibrium with nonrenegotiable debt always exists. A corner equilibrium with renegotiable debt exists only if the bargaining power of creditors is such that

$$
\omega \leq \hat{\omega}
$$

where $\hat{\omega}$ is larger than $\omega^{*}$ but smaller than one.

Proof. See the Appendix.

In a corner equilibrium with n-debt, the sovereign does not increase domestic welfare by accepting an offer from an r-lender. By accepting such an offer, it would raise only the payoff of the n-creditors, who see the value of their claims increase, since a marginal switch to r-debt reduces the probability of default.

In contrast, a corner equilibrium with r-debt is more vulnerable to aggressive bidding by excluded lenders. Any n-lender can then offer debt at a lower interest rate than r-creditors, because of the effective seniority of n-debt in selective defaults. The sovereign could then benefit 
from a marginal deviation to n-debt, at the expense of the outstanding r-creditors who see the value of their claims decrease.

An interesting implication of this lemma is that the corner equilibrium with renegotiable debt does not exist if the bargaining power of creditors is large. This may seem paradoxical, since r-creditors should then worry less about a selective default. To understand this result, consider the effect of a marginal increase in n-debt, $d D_{n}>0$, associated with a marginal decrease in r-debt, $d D_{r}<0$, at a corner equilibrium with r-debt. The n-lenders are ready to provide the new debt at price $P_{n}=1$ since the probability of a full default is infinitesimal. The impact of this marginal debt swap on the total value of debt can be obtained by differentiating (3), setting $D_{n}=0$, and using $d D_{r}=-d D_{n} / P_{r}$ :

$$
d U=-d D_{n}+\omega \int_{0}^{D_{r} / \omega} f(y) d y d D_{n}+\int_{D_{r} / \omega}^{+\infty} f(y) d y \frac{d D_{n}}{P_{r}} .
$$

The first term on the right-hand side corresponds to the repayment of the new n-debt. The second term corresponds to the reduction in the repayment to r-creditors caused by the de facto seniority of n-debt in selective defaults. Finally, the last term corresponds to the reduction in the total face value of $r$-debt. A corner equilibrium with $r$-debt cannot exist if $d U>0$, that is, if the second and third terms on the right-hand side of (11) are large enough.

The negative externality of n-debt on r-debt in selective defaults, which is captured by the second term on the right-hand side of (11), is proportional to the bargaining power of creditors $\omega$. The reason is that the externality at work in a selective default is essentially a transfer of debt recovery value from $\mathrm{r}$-creditors to $\mathrm{n}$-creditors. The expropriation of r-creditors by n-creditors, thus, is proportional to the recovery value that the r-creditors would receive in the absence of n-creditors, that is, to their bargaining power. This explains why r-creditors' greater bargaining power actually increases the negative externality imposed by n-debt.

We are now ready to characterize the set of Nash equilibria.

Proposition 3.

1. There are two types of Nash equilibria: a corner equilibrium with nonrenegotiable debt, which always exists, and a corner equilibrium with renegotiable debt, which exists if and only if $\omega \in\left[\omega^{*}, \hat{\omega}\right]$.

2. There are two Pareto-ranked corner equilibria if $\omega \in\left[\omega^{*}, \hat{\omega}\right]$ : an inefficient equilibrium with nonrenegotiable debt and an efficient equilibrium with renegotiable debt.

Proof. The proposition follows from lemma 2 and proposition 2. It is possible to finance the expenditure $g$ with n-debt because of our assumption that $\max _{D_{n}} V\left(0, D_{n}\right) \geq g$. By lemma 4 the corner equilibrium with n-debt always exists. 


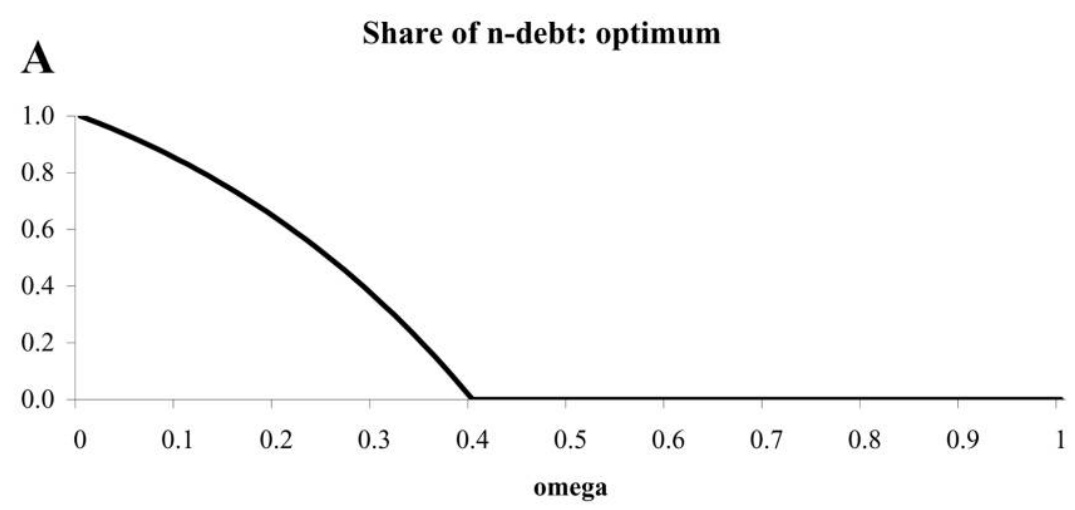

Share of n-debt: laissez-faire

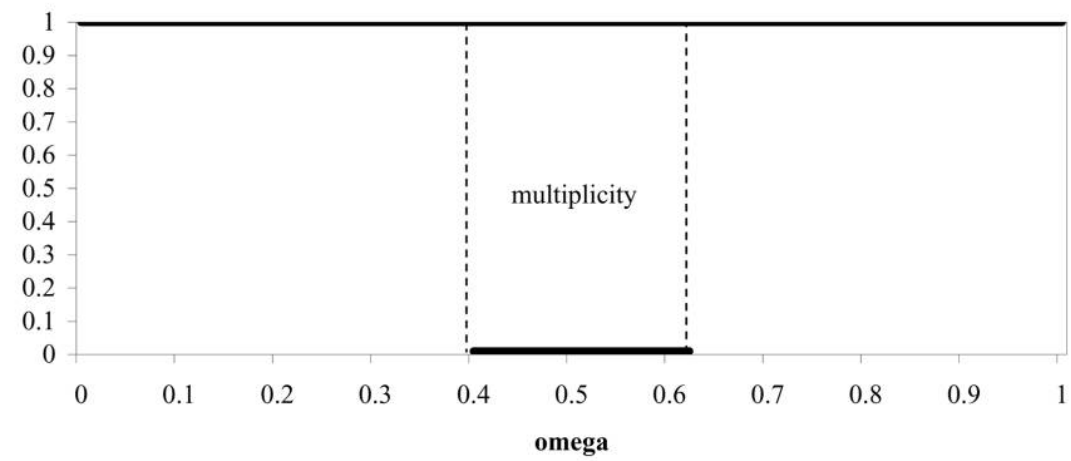

Fig. 2.-Share of nonrenegotiable debt in total debt. Source: authors' computations. The figure shows the share of n-debt in total debt repayment, $P_{n} D_{n} / g$, as a function of the creditors' bargaining power $\omega$, at the optimum (panel $A$ ) and under laissez-faire (panel $B)$. The figure is constructed under the assumption that $y$ is uniformly distributed in $[0$, 2] and $g=0.4$.

Two conditions must be met for the corner equilibrium with r-debt to exist. First, $\omega$ must be high enough to allow the sovereign to pledge enough output to finance $g$, that is, $\max _{D_{r}} V\left(D_{r}, 0\right) \geq g$. By proposition 2 this is true if and only if $\omega \geq \omega^{*}$. Second, $\omega$ must be smaller than $\hat{\omega}$ by lemma 2 . Thus the corner equilibrium with r-debt exists if and only if $\omega \in\left[\omega^{*}, \hat{\omega}\right]$. This interval is nonempty by lemma 2 .

When $\omega \in\left[\omega^{*}, \hat{\omega}\right]$, the conditions for the existence of an r-debt equilibrium and n-debt equilibrium are simultaneously satisfied. Finally, since the r-debt equilibrium involves no deadweight cost of default, it strictly dominates the n-debt equilibrium. QED

The equilibria are illustrated in figure 2 , which is constructed assuming that $y$ is uniformly distributed in $[0,2]$ and that $g=0.4$. This spec- 
ification implies $\omega^{*}=0.4$ and $\hat{\omega}=0.625 .{ }^{13}$ The figure shows how the share of nonrenegotiable debt in total debt, $P_{n} D_{n} / g$, varies with the bargaining power of the creditors, at the optimum (fig. $2 A$ ) and in the laissez-faire equilibrium (fig. $2 B$ ).

The only value of $\omega$ for which the set of laissez-faire equilibria coincides with the optimum is $\omega=0$. If $\omega>0$, there is a corner equilibrium with nonrenegotiable debt, which is inefficient since the optimal debt structure involves some renegotiable debt. Recall that when lenders' ex post bargaining power is sufficiently strong (so that $\omega>\omega^{*}$ ), the optimal debt structure is for the sovereign to issue only r-debt. As proposition 3 highlights, there also exists a range $\omega \in\left[\omega^{*}, \hat{\omega}\right]$ for which a socially efficient r-debt equilibrium exists.

As figure 2 suggests and the next proposition confirms, there is generally too much n-debt issued when an equilibrium exists. This is, of course, consistent with our broad intuition that n-debt tends to drive out r-debt.

Proposition 4 (Gresham law for sovereign debt). The socially optimal amount of n-debt is less than or equal to the amount of n-debt issued in a Nash equilibrium for all $\omega$.

Proof. If the unique Nash equilibrium is the corner equilibrium with $\mathrm{n}$-debt, then there is too much n-debt in equilibrium, since, from proposition 2, the socially optimal fraction of $n$-debt is strictly less than one for $\omega>0$. If the unique Nash equilibrium is the corner equilibrium with r-debt, the amount of n-debt is equal to the socially optimal level. QED

\section{Public Policy}

Given the complex effects of lender bargaining power in debt renegotiations on equilibrium debt structure, there is no simple welfareimproving policy intervention even in the highly simplified setting of our model. In reality, of course, the policy intervention in sovereign debt restructuring is even more complex, so much so that the debates on the bankruptcy regime for sovereigns have not resulted in any new policy initiative. The most notable new development has been a more widespread introduction of CACs in sovereign bond issues, partly in response to pressure by the U.S. Treasury Department and partly as a way of preempting a more far-reaching and threatening intervention (see Gelpern and Gulati 2007).

In terms of our model, this shift toward CACs can be interpreted as a shift toward r-debt, and to the extent that there is too much n-debt in equilibrium, this shift might be seen as a desirable step. However,

\footnotetext{
${ }^{13}$ Closed-form solutions for the equilibrium can be derived in the case of a uniform distribution. The details are available from the authors on request.
} 
note that a purely voluntary shift from n-debt to r-debt can be welfare improving in our model only in the situation in which there are multiple equilibria. In that case, it is conceivable that mild public pressure and moral suasion could serve as an equilibrium selection device and induce a switch from the n-debt corner equilibrium to an r-debt equilibrium.

In all other situations, a purely voluntary approach to CACs is unlikely to work, and the implementation of some form of bankruptcy regime for sovereigns is necessary to facilitate debt renegotiations. As our analysis makes clear, however, the introduction of a bankruptcy regime for sovereigns has both benefits and costs and may sometimes be counterproductive. Indeed, suppose that all debt becomes renegotiable under the bankruptcy regime. Then the cost of this policy in our model is that when $\omega<\omega^{*}$, the sovereign, unable to issue n-debt, will be credit rationed. This outcome is precisely what commentators on sovereign debt restructuring such as Dooley (2000) and Shleifer (2003) have been concerned about.

The bankruptcy regime is strictly beneficial only if lenders' bargaining power is sufficiently high: $\omega>\omega^{*}$. In that case, the sovereign is able to borrow in the form of r-debt, and the elimination of $n$-debt brings about lower costs of sovereign debt crises without raising the cost of borrowing for the sovereign. Thus, the analysis in our model highlights that in the debate on the bankruptcy regime for sovereigns the advocates for reform (Krueger) as well as the critics (Dooley, Shleifer) could have been right. To the extent that the proponents of a bankruptcy regime had in mind a world with relatively high lender bargaining power or envisioned a bankruptcy institution in which lenders would have adequate protection, they correctly pointed to the net welfare benefits of eliminating access to n-debt for sovereign borrowers. If the critics had in mind a world with lower lender bargaining power, they also correctly pointed to the risks of undermining the sovereign bond market, if the restructuring of bonds was facilitated.

Our analysis suggests two ways of reconciling these differences of opinion. One is to make sure that lenders have sufficient bargaining power in a bankruptcy regime for sovereigns. The other is to allow issuers to opt out ex ante from the bankruptcy procedure. In other words, a policy that lets the sovereign decide whether it wants to allow for n-debt or not would guarantee that the policy intervention is always welfare improving. Thus, in our model the optimal policy is as described in the proposition below.

Proposition 5. A bankruptcy regime that makes the sovereign debt renegotiable is optimal if and only if either

1. the regime guarantees a bargaining power to lenders such that $\omega \geq \omega^{*}$ or 
2. the sovereign can choose to opt out of the bankruptcy regime ex ante.

Proof. See the discussion above.

We close our discussion of public policy with a note of caution, since our analysis here is restrictive in one important respect. By assuming that the amount the sovereign borrows, $g$, is fixed and known, we have eliminated an important externality in sovereign debt markets: dilution of outstanding debts by new pari passu debt issues. If the sovereign cannot commit not to borrow more than $g$, then early lenders will seek to protect themselves against this risk of dilution by issuing n-debt, which de facto has higher priority. We pursue the analysis of this situation in Bolton and Jeanne (2005) and show that when the sovereign cannot commit to a fixed amount of borrowing $g$, then an efficient international bankruptcy regime for sovereigns must also establish a form of seniority or absolute priority rule.

\section{Conclusion}

This article presents a model of sovereign debt crises that, although stylized, is versatile enough to lend itself to the analysis of a number of questions that have been discussed in the recent debates on the international financial architecture. The endogeneity of the debt structure implies that the normative analysis has to go beyond statements that debt workouts should be made more orderly and sovereign creditors coordinated in a crisis. These statements are correct in an ex post sense, but from an ex ante perspective, debt structures with nonrenegotiable debt arise for a reason.

At the same time, our analysis does not support a Panglossian view that sovereign debt contracts are efficient ex ante and that there is no scope for welfare-improving reforms. We do find that sovereign debt might be excessively difficult to restructure under laissez-faire (even from an ex ante point of view) and that public intervention is warranted.

This model abstracted from a number of issues that may be quite relevant in the real world. One such issue is debt maturity. Short-term debt is another way of deflecting selective defaults. However, short-term debt could make sovereigns excessively vulnerable to debt rollover crises (Jeanne 2004). This issue is addressed in Bolton and Jeanne (2005) and requires a different form of intervention than the simple facilitation of debt renegotiations. Our analysis could also be extended to take into consideration other agency problems than those between debtors and creditors, in particular, political agency problems between citizens and their governments. In our model it is unambiguously optimal to relax the credit constraints in the international debt market because governments are assumed to be benevolent. The welfare analysis could be very 
different if decisions are made by self-interested policy makers who do not maximize domestic welfare. Rationing the debt granted to policy makers, then, could conceivably increase the welfare of their citizens.

\section{Appendix}

\section{Proof of Lemma 1}

Consider an interior equilibrium $\left(D_{r}, D_{n}\right)$ with $D_{r}>0$ and $D_{n}>0$. Then the firstorder condition of the sovereign's problem implies that a marginal change in the debt structure such that $\left(d D_{n} / d_{n}\right)+\left(d D_{r} / d_{r}\right)=0$ has a zero first-order effect on the sovereign's welfare, $d U=0$. We then show that the second-order effect,

$$
d^{2} U=\frac{\partial^{2} U}{\partial D_{r}^{2}} d D_{r}^{2}+2 \frac{\partial^{2} U}{\partial D_{r} \partial D_{n}} d D_{r} d D_{n}+\frac{\partial^{2} U}{\partial D_{n}^{2}} d D_{n}^{2},
$$

is positive (i.e., $U$ is strictly convex), implying that $\left(D_{n}, D_{n}\right)$ cannot be an equilibrium.

Using (3), one can compute

$$
\begin{gathered}
\frac{\partial U}{\partial D_{n}}=-(1-\omega) \int_{D_{n}}^{D_{n}+\left(D_{r} / \omega\right)} f(y) d y-\int_{D_{n}+\left(D_{r} / \omega\right)}^{+\infty} f(y) d y, \\
\frac{\partial U}{\partial D_{r}}=-\int_{D_{n}+\left(D_{r} / \omega\right)}^{+\infty} f(y) d y \\
\frac{\partial^{2} U}{\partial D_{n}^{2}}=(1-\omega) f\left(D_{n}\right)+\omega f\left(D_{n}+\frac{D_{r}}{\omega}\right), \\
\frac{\partial^{2} U}{\partial D_{n} \partial D_{r}}=f\left(D_{n}+\frac{D_{r}}{\omega}\right) \\
\frac{\partial^{2} U}{\partial D_{r}^{2}}=\frac{1}{\omega} f\left(D_{n}+\frac{D_{r}}{\omega}\right) .
\end{gathered}
$$

Substituting these expressions into (A1) in turn gives

$$
d^{2} U=(1-\omega) f\left(D_{n}\right) d D_{n}^{2}+\frac{1}{\omega} f\left(D_{n}+\frac{D_{r}}{\omega}\right)\left(\omega d D_{n}+d D_{r}\right)^{2}>0,
$$

which proves the lemma. QED

Proof of Lemma 2

We determine whether a corner equilibrium exists by checking whether condition (10) is satisfied. Let us start with the case of a corner equilibrium with r-debt $\left(D_{n}=0\right)$. This equilibrium is robust to bidding by n-creditors offering 
$d D_{n}>0$ if and only if

$$
d U=\left(-\frac{1}{1+\alpha} \frac{P_{n}}{P_{r}} \frac{\partial U}{\partial D_{r}}+\frac{\partial U}{\partial D_{n}}\right) d D_{n} \leq 0 .
$$

For simplicity we consider the limit case in which the deviating n-lenders make fair bids $(\alpha=0)$. Using $P_{n}=1$, (A2) and (A3) with $D_{n}=0$, and $P_{r} D_{r}=g$, one has

$$
\begin{aligned}
\frac{d U}{d D_{n}} & =\frac{D_{r}}{g} \int_{D_{r} / \omega}^{+\infty} f(y) d y-(1-\omega) \int_{0}^{D_{r} / \omega} f(y) d y-\int_{D_{r} / \omega}^{+\infty} f(y) d y \\
& =\frac{\omega}{g} \int_{0}^{D_{r} / \omega}(g-y) f(y) d y,
\end{aligned}
$$

where the second equality is obtained by substituting out $D_{r}$ using the zero-profit condition for the r-lenders:

$$
\int_{0}^{D_{r} / \omega} \omega y f(y) d y+D_{r} \int_{D_{r} / \omega}^{+\infty} f(y) d y=g .
$$

We define the function $h: \omega \mapsto \int_{0}^{D_{r} / \omega}(g-y) f(y) d y$ and show that there exists a threshold $\hat{\omega} \in\left[\omega^{*}, 1\right]$ such that $h(\omega)$ is negative if and only if $\omega \leq \hat{\omega}$. It will follow that condition (10), $d U / d D_{n} \leq 0$, is satisfied if and only if $\omega \leq \hat{\omega}$, as stated in the lemma.

To establish that $\hat{\omega}$ exists, we show first that $h(\cdot)$ is increasing in $\omega$. Dividing (A4) by $\omega$ gives

$$
\frac{g}{\omega}=\int_{0}^{m(\omega)} y f(y) d y+m(\omega) \int_{m(\omega)}^{+\infty} f(y) d y,
$$

where $m(\omega)=D_{r} / \omega$. Differentiating this expression with respect to $\omega$, we see that $m^{\prime}(\omega)<0$. From $g<D_{r} \leq D_{r} / \omega=m(\omega)$, it follows that

$$
h^{\prime}(\omega)=m^{\prime}(\omega)[g-m(\omega)] f(m(\omega))>0 .
$$

The existence of $\hat{\omega} \in\left[\omega^{*}, 1\right]$ then follows from the facts that $h\left(\omega^{*}\right)<0$ and $h(1)>0$. To establish the first inequality, note that since $\lim _{\omega \rightarrow \omega^{*}} m(\omega)=+\infty$, we have $h\left(\omega^{*}\right)=g-E(y)<0$. The second inequality follows from equation (A4), which for $\omega=1$ reduces to

$$
h(1)=\int_{0}^{D_{r}}(g-y) f(y) d y=\left(D_{r}-g\right) \int_{D_{r}}^{+\infty} f(y) d y>0,
$$

where the second equality uses (A4) and the inequality uses $D_{r}>g$.

Finally, we consider the existence of a corner equilibrium with n-debt $\left(D_{r}=0\right)$. By condition (10) this equilibrium is robust to bidding by r-creditors offering $d D_{r}>0$ if and only if

$$
d U=\left(-\frac{1}{1+\alpha} \frac{P_{r}}{P_{n}} \frac{\partial U}{\partial D_{n}}+\frac{\partial U}{\partial D_{r}}\right) d D_{r} \leq 0 .
$$

We then compute the terms in this condition using (5), (6), (A2), and (A3) with $D_{r}=0$. Note that we have $P_{r}=P_{n}=\int_{D_{n}}^{+\infty} f(y) d y$ since the first term on the right-hand side of (5) converges to zero as $D_{r}$ goes to zero. Condition (10) 
becomes

$$
d U=-\frac{\alpha}{1+\alpha} \int_{D_{n}}^{+\infty} f(y) d y d D_{r} \leq 0,
$$

which is true. Thus the corner equilibrium with n-debt always exists. ${ }^{14}$ QED

\section{References}

Beers, David T., and John Chambers. 2003. "Sovereign Defaults: Heading Lower into 2004." Standard and Poor's Credit Week, September 18. http://www .creditweek.com.

Bernheim, B. Douglas, and Michael D. Whinston. 1986a. "Common Agency." Econometrica 54 (July): 923-42.

. 1986b. "Menu Auctions, Resource Allocation, and Economic Influence." Q.J.E. 101 (February): 1-31.

Bolton, Patrick, and Olivier Jeanne. 2005. "Structuring and Restructuring Sovereign Debt: The Role of Seniority.” Working Paper no. 11071 (January), NBER, Cambridge, MA.

Bolton, Patrick, and David S. Scharfstein. 1996. "Optimal Debt Structure and the Number of Creditors." J.P.E. 104 (February): 1-25.

Buchheit, Lee C., and Mitu Gulati. 2000. "Exit Consents in Sovereign Bond Exchanges." UCLA Law Rev. 48 (October): 59-84.

Bulow, Jeremy, and Kenneth Rogoff. 1989. "A Constant Recontracting Model of Sovereign Debt.” J.P.E. 97 (February): 155-78.

. 1991. "Sovereign Debt Repurchases: No Cure for Overhang." Q.J.E. 106 (November): 1219-35.

Dewatripont, Mathias, and Eric Maskin. 1995. "Credit and Efficiency in Centralized and Decentralized Economies." Rev. Econ. Studies 62 (October): 54155 .

Diamond, Douglas W. 2004. "Committing to Commit: Short-Term Debt When Enforcement Is Costly.” J. Finance 59 (August): 1447-79.

Diamond, Douglas W., and Raghuram G. Rajan. 2001. "Liquidity Risk, Liquidity Creation, and Financial Fragility: A Theory of Banking." J.P.E. 109 (April): 287-327.

Dooley, Michael P. 2000. "Can Output Losses Following International Financial Crises Be Avoided?” Working Paper no. 7531 (February), NBER, Cambridge, MA.

Eaton, Jonathan, and Mark Gersovitz. 1981. "Debt with Potential Repudiation: Theory and Empirical Analysis.” Rev. Econ. Studies 48 (April): 289-309.

Eichengreen, Barry. 2003. "Restructuring Sovereign Debt." J. Econ. Perspectives 17 (Fall): 75-98.

G-10 (Group of 10). 1996. Resolving Sovereign Liquidity Crises. Washington, DC: G-10.

G-22 (Group of 22). 1998. Three Reports on International Financial Architecture Reform. Washington, DC: G-22.

Gelpern, Anna, and Mitu Gulati. 2007. "Public Symbol in Private Contract: A Case Study." Washington Univ. Law Rev. 84 (7): 1627-1715.

${ }^{14}$ We are assuming that $\alpha$ is not infinitesimal. If it were, then $d U$ would be second-order, implying that we would need to differentiate $U$ to the second order to include all the relevant terms. This assumption is plausible if the r-lender bears a small cost of deviating from the equilibrium. 
Hart, Oliver, and John Moore. 1995. "Debt and Seniority: An Analysis of the Role of Hard Claims in Constraining Management." A.E.R. 85 (June): 56785.

Hart, Oliver, and Jean Tirole. 1990. "Vertical Integration and Market Foreclosure.” Brookings Papers Econ. Activity: Microeconomics, pp. 205-86.

Jeanne, Olivier. 2004. "Debt Maturity and the International Financial Architecture.” Working Paper no. 04/137 (July), Internat. Monetary Fund, Washington, DC.

Kenen, Peter B. 2001. The International Financial Architecture: What's New? What's Missing? Washington, DC: Inst. Internat. Econ.

Krueger, Anne O. 2002. A New Approach to Sovereign Debt Restructuring. Washington, DC: Internat. Monetary Fund.

Merrill Lynch. 1995. The 1995 Guide to Brady Bonds. New York: Merrill Lynch.

Obstfeld, Maurice, and Kenneth Rogoff. 1996. Foundations of International Macroeconomics. Cambridge, MA: MIT Press.

Peterson, Michael. 1999. "A Crash Course in Default." Euromoney, no. 366 (October): 47-50.

Rogoff, Kenneth, and Jeromin Zettelmeyer. 2002. "Bankruptcy Procedures for Sovereigns: A History of Ideas, 1976-2001.” IMF Staff Papers 49 (3): 470-507.

Roubini, Nouriel, and Brad Setser. 2004. Bailouts or Bail-ins? Responding to Financial Crises in Emerging Economies. Washington, DC: Inst. Internat. Econ.

Sachs, Jeffrey, and Daniel Cohen. 1982. "LDC Borrowing with Default Risk." Working Paper no. 925 (July), NBER, Cambridge, MA.

Segal, Ilya. 1999. "Contracting with Externalities." Q.J.E. 114 (May): 337-88.

Shleifer, Andrei. 2003. "Will the Sovereign Debt Market Survive?" A.E.R. Papers and Proc. 93 (May): 85-90.

Sturzenegger, Federico, and Jeromin Zettelmeyer. 2006. Debt Defaults and Lessons from a Decade of Crises. Cambridge, MA: MIT Press.

Tirole, Jean. 2002. Financial Crises, Liquidity, and the International Monetary System. Princeton, NJ: Princeton Univ. Press.

Zettelmeyer, Jeromin. 2003. "The Case for an Explicit Seniority Structure in Sovereign Debt." Manuscript, Internat. Monetary Fund, Washington, DC. 